Article

\title{
Novel Carbon/PEDOT/PSS-Based Screen-Printed Biosensors for Acetylcholine Neurotransmitter and Acetylcholinesterase Detection in Human Serum
}

\author{
Nashwa H. Ashmawy ${ }^{1}$, Abdulrahman A. Almehizia ${ }^{2}{ }^{\mathbb{D}}$, Teraze A. Youssef ${ }^{1}$, \\ Abd El-Galil E. Amr 3,4,*(D), Mohamed A. Al-Omar 2,3 (D) and Ayman H. Kamel 1,*(D) \\ 1 Chemistry Department, Faculty of Science, Ain Shams University, P.O. Cairo 11566, Egypt; \\ nashwastar20@yahoo.com (N.H.A.); trease_albert@yahoo.com (T.A.Y.) \\ 2 Pharmaceutical Chemistry Department, College of Pharmacy, King Saud University, \\ Riyadh 1451, Saudi Arabia; mehizia@ksu.edu.sa (A.A.A.); malomar1@ksu.edu.sa (M.A.A.-O.) \\ 3 Pharmaceutical Chemistry Department, Drug Exploration \& Development Chair (DEDC), \\ College of Pharmacy, King Saud University, Riyadh 11451, Saudi Arabia \\ 4 Applied Organic Chemistry Department, National Research Centre, Dokki, Giza 12622, Egypt \\ * Correspondence: aamr@ksu.edu.sa (A.E.-G.E.A.); ahkamel76@sci.asu.edu.eg (A.H.K.); \\ Tel.: +966-565-148-750 (A.E.-G.E.A.); +201000361328 (A.H.K.)
}

Academic Editor: Roberto Fernandez-Lafuente

Received: 28 March 2019; Accepted: 16 April 2019; Published: 18 April 2019

\begin{abstract}
New reliable and robust potentiometric ion-selective electrodes were fabricated using poly(3,4-ethylenedioxythiophene)/poly(styrenesulfonate) (PEDOT/PSS) as the solid contact between the sensing membrane and electrical substrate for an acetylcholine (ACh) bioassay. A film of PEDOT/PSS was deposited on a solid carbon screen-printed platform made from ceramic substrate. The selective materials used in the ion-selective electrode (ISE) sensor membrane were acetylcholinium tetraphenylborate (ACh/TPB/PEDOT/PSS-ISE) (sensor I) and triacetyl- $\beta$-cyclodextrin ( $\beta$-CD/PEDOT/PSS-ISE) (sensor II). The sensors revealed clear enhanced Nernstian response with a cationic slope $56.4 \pm 0.6$ and $55.3 \pm 1.1 \mathrm{mV} /$ decade toward $\left(\mathrm{ACh}^{+}\right)$ions over the dynamic linear range $1.0 \times 10^{-6}-1 \times 10^{-3}$ and $2.0 \times 10^{-6}-1.0 \times 10^{-3} \mathrm{M}$ at $\mathrm{pH} 5$ with limits of detection $2.0 \times 10^{-7}$ and $3.2 \times 10^{-7} \mathrm{M}$ for sensors I and II, respectively. The selectivity behavior of both sensors was also tested and the sensors showed a significant high selectivity toward $\mathrm{ACh}^{+}$over different common organic and inorganic cations. The stability of the potential response for the solid-contact (SC)/ISEs was evaluated using a chronopotentiometric method and compared with that of electrodes prepared without adding the solid-contact material (PEDOT/PSS). Enhanced accuracy, excellent repeatability, good reproducibility, potential stability, and high selectivity and sensitivity were introduced by these cost-effective sensors. The sensors were also used to measure the activity of acetylcholinesterase (AChE). A linear plot between the initial rate of the hydrolysis of $\mathrm{ACh}^{+}$substrate and enzyme activity held $5.0 \times 10^{-3}-5.2 \mathrm{IU} \mathrm{L}^{-1}$ of AChE enzyme. Application to acetylcholine determination in human serum was done and the results were compared with the standard colorimetric method.
\end{abstract}

Keywords: solid-contact/ISEs; PEDOT/PSS; acetylcholine; biosensors; acetylcholinesterase

\section{Introduction}

Neurotransmitters are classified as important endogenous chemical messengers. These messengers transmit and enhance specific signals between neurons and other cells. They have an important role in behavior and cognition functions in the brain. In addition, they can play an important role in muscle tone and heart rate adjustment. Also, they are responsible for regulation of learning, sleeping, memory, consciousness, mood, and appetite in human bodies [1,2]. Acetylcholine (ACh) can be 
considered as one of the oldest neurotransmitters in the animal kingdom in both peripheral and central nervous systems [2]. It binds to its specific receptors to regulate muscle contraction in the peripheral nervous system. On the other hand, it plays an essential role in the central nervous system in the processes related to behavioral activities. In neurons, ACh is prepared from choline using choline acetyltransferase (ChAT) and acetylcoenzyme A [1-3]. The level of ACh in human blood is $\sim 0.52 \mu \mathrm{M}$ in males and $\sim 0.47 \mu \mathrm{M}$ in females [4]. ACh also has a therapeutic utility as an intraocular irrigating fluid [5]. On the other hand, a lack of ACh can cause disturbance in the transmission of nerve impulses, paralysis, and death [6].

From all of the above, the level of ACh in human blood is very critical and it is very important to find an analytical tool to trace its level in the human body. The development of reliable and robust analytical devices for fast and sensitive assessment of ACh was a great challenging target for many years. ACh is not ultraviolet (UV)-absorbing, has no fluorescence signal, and is not derivatizable. Thus, tracing of ACh is a challenging analytical problem. Therefore, only tedious procedures such as bioassays [7], methods based on radiochemical analysis [8], enzymatic-based liquid chromatography (LC) [9-12], and mass spectrometric detection-based LC [13-16] are often used. In addition, theses reported methods have several disadvantages, such as a long analysis time, high cost analysis, and the requirement of highly skilled people specialized with laboratory facilities.

Electroanalytical techniques provide many advantages such as simple equipment used for analysis, ease of use, and a short time taken for analysis. Uni-, bi-, and tri-enzyme/mediator biosensors including chemiluminometric [17], amperometric [18-20], conductometric [21], and voltammetric [22] methods are conducted for ACh monitoring. On the other hand, all these mentioned methods suffer from a long analysis time and the need for specialized personnel with laboratory facilities.

In comparison with different techniques, potentiometric ion-selective electrodes (ISEs) have some unique performance characteristics, such as ease of miniaturization, ease of handling, portability, and low cost [23-26]. Recently, solid-state potentiometric ion-selective sensors revealed a tremendous ability to analyze biological, biomedical, and environmental samples [27-29]. The configuration of all-solid-state ISEs seems suitable for miniaturized sensor fabrication characterized with good analytical characteristics to detect different ions in different matrices.

As cited in the literature, few potentiometric ion-selective electrodes (ISEs) were developed [30-36]. Some of them include ion-pair complexes of acetylcholine as electro-active materials. These revealed limited linear range and a long response time of analysis [30-32]. The others include macrocycle carriers such as $\beta$-cyclodextrin and molecularly imprinted polymers $[33,35,36]$. It is interesting to compare the selectivity and working of the proposed ACh electrode along with those reported before (Table 1). Traditional potentiometric ISE configurations containing inner filling solution presented good performance characteristics for benchtop ion sensing. However, this configuration fails with small-volume samples. These types of samples need to be addressed along with the requirements of miniaturization. Considering in vivo biomedical analysis, the use of liquid-contact ion-selective electrodes (ISEs) has many drawbacks. For example, the inner filling solution is subjected to evaporation, as well as changes in temperature and pressure of the sample. In addition, osmotic pressure can be caused due to differences in the ionic strength of the sample and the inner filling solution. This arisen osmotic pressure can produce a net liquid transport from/to the inner filling solution and lead to volume changes. This can provoke delamination of the ISM [37]. As an example of solid-contact electrodes, screen-printed electrodes were shown to be a good technique for sensor miniaturization, as they are simple, cheap, and easy to be fabricated for mass production. These good features of screen-printed electrodes make such electrode types promising for the detection of organic species. 
Table 1. General characteristics of some potentiometric sensors for acetylcholine determination.

\begin{tabular}{|c|c|c|c|c|c|c|}
\hline Ionophore & $\begin{array}{c}\text { Slope, } \\
\left(\mathrm{mV} \text { Decade }^{-1}\right)\end{array}$ & Linear Range, (M) & Detection Limit, (M) & pH Range & Interference & Ref. \\
\hline Acetylcholine dipicrylaminate & 54.4 & $5.0 \times 10^{-5}-1.0 \times 10^{-2}$ & $3.0 \times 10^{-5}$ & NR & $\begin{array}{c}\text { Choline (-1.35); butyrylcholine (-1.02); dopamine } \\
(-2.21) \text {; tyrosine }(-2.39) ; \text { aminobutyric acid }(-2.82) ; \\
\text { carbachol (-1.43); amphetamine }(-1.06) ; \mathrm{K}^{+}(-2.65) \\
\mathrm{NH}_{4}{ }^{+}(-3.39)\end{array}$ & [30] \\
\hline Cucurbit(6)uril derivative & 49.1 & $1.0 \times 10^{-6}-1.0 \times 10^{-3}$ & $9.70 \times 10^{-7}$ & 7.2 & $\begin{array}{c}\text { choline }(-2.51) ; \mathrm{NH}_{4}{ }^{+}(-1.96) ; \mathrm{NMe}_{4}{ }^{+}(-1.93) ; \mathrm{NEt}_{4}{ }^{+} \\
(-1.93) ; \mathrm{K}^{+}(-1.57) ; \mathrm{Na}^{+}(-1.83) ; \mathrm{dopamine}^{-}(-1.51) \\
\text { ascorbic acid }(-2.45)\end{array}$ & [31] \\
\hline Dioctyloctadecylamine & 41.4 & $3.0 \times 10^{-6}-4.5 \times 10^{-5}$ & $2.0 \times 10^{-6}-5.0 \times 10^{-6}$ & 8.0 & NR & \\
\hline $\begin{array}{l}N, N \text {-didecyl-aminomethyl } \\
\text {-benzene }\end{array}$ & 52.9 & $1.0 \times 10^{-5}-8.0 \times 10^{-3}$ & $5.0 \times 10^{-6}$ & 8.0 & NR & [32] \\
\hline Tetrakis( $p$-chloro-phenyl) borate & NR & NR & $1.0 \times 10^{-5}$ & 6 & NR & \\
\hline Dibenzo-18-crown-6 & NR & NR & $1.0 \times 10^{-5}$ & 6 & NR & [33] \\
\hline Calix[6]arene hexaester & NR & NR & $1.7 \times 10^{-5}$ & 6 & NR & \\
\hline$\beta$-Cyclodextrin $(\beta-C D)$ derivative & 55.6 & $1.00 \times 10^{-5}-1.0 \times 10^{-2}$ & $2.70 \times 10^{-6}$ & $3.0-10$ & $\begin{array}{c}\text { Choline (-2.50); } \mathrm{NH}_{4}^{+}(-3.80) \text {; citrate }(-2.53) ; \mathrm{Li}^{+} \\
(-3.76) ; \mathrm{K}^{+}(-3.89) ; \text { caffeine }(-2.30)\end{array}$ & [34] \\
\hline $\begin{array}{l}\text { Molecularly imprinted polymer } \\
\text { (MIP) based on methacrylic acid } \\
\text { monomer (MAA) and } \\
\text { tetraphenylborate (TPB) additive }\end{array}$ & 55.2 & $1.00 \times 10^{-5}-1.0 \times 10^{-2}$ & $4.5 \times 10^{-6}$ & $3.0-9.0$ & $\begin{array}{l}\text { Glutamine }(-1.52) \text {; codeine }(-1.37) \text {; ephedrine }(-1.45) \text {; } \\
\text { morphine }(-1.50) \text {; caffeine }(-1.5) \text {; quinine }(-1.57) ; \\
\text { histidine }(-1.60) \text {; choline }(-1.62) \text { cysteine }(-1.70) ; \mathrm{K}^{+} \\
(-2.51) ; \mathrm{Ca}^{2+}(-2.54) ; \mathrm{Mg}^{2+}(-2.82) ; \mathrm{Ba}^{2+}(-2.93)\end{array}$ & [35] \\
\hline $\begin{array}{l}\text { Multiwall carbon nanotubes } \\
\text { (MWCNTs) and aniline (ANI) in } \\
\text { bulk imprinting. }\end{array}$ & 75.9 & $3.45 \times 10^{-5}-1.0 \times 10^{-2}$ & $3.13 \times 10^{-5}$ & 4.0 & $\begin{array}{c}\text { Creatinine }(-0.04) \text {, creatine }(+0.82) \text {, cysteine }(+0.08) \text {, } \\
\text { glutamine }(-0.35), \text { urea }(-0.23)\end{array}$ & [36] \\
\hline ACh/TPB/PEDOT/PSS-ISE & $56.4 \pm 0.6$ & $1.00 \times 10^{-6}-10 \times 10^{-3}$ & $2.0 \times 10^{-7}$ & $4.5-10$ & $\begin{array}{c}\text { Choline }(-3.3) \text {, urea }(-4.2) \text {, hexamine }(-4.3) \text {, ethylene } \\
\text { diamine }(-6.2) \text {, dimethylamine }(-3.2) \text {, hydroxylamine } \\
(-3.1), \text { methylamine }(-3.3) \text {, histidine }(-4.5) \text {, alanine } \\
(-4.4) \text {, ephedrine }(-3.3) \text {, codeine }(-2.7), \text { morphine } \\
(-2.9), \mathrm{K}^{+}(-5.3) ; \mathrm{Ca}^{2+}(-6.8) ; \mathrm{Mg}^{2+}(-7.1) ; \mathrm{Na}^{+}(-5.3) \\
\text { Choline }(-3.5) \text {, urea }(-4.5) \text {, hexamine }(-4.1) \text {, ethylene } \\
\text { diamine }(-6.1) \text {, dimethylamine }(-4.9) \text {, hydroxylamine } \\
(-4.8) \text {, methylamine }(-4.5) \text {, histidine }(-4.1) \text {, alanine } \\
(-4.3) \text {, ephedrine }(-1.2), \text { codeine }(-1.0), \text { morphine } \\
(-1.1), \mathrm{K}^{+}(-5.1) ; \mathrm{Ca}^{2+}(-7.1) ; \mathrm{Mg}^{2+}(-7.3) ; \mathrm{Na}^{+}(-6.2) \text {. }\end{array}$ & $\begin{array}{l}\text { This } \\
\text { work }\end{array}$ \\
\hline
\end{tabular}


Herein, we present novel robust, reliable potentiometric solid-contact ISEs for trace determination of acetylcholine. A poly(3,4-ethylenedioxythiophene)/poly(styrenesulfonate) (PEDOT/PSS) film was used as the solid contact. The sensors were introduced for the determination of ACh under static and hydrodynamic modes of operation. The proposed sensors were also applied for simple, sensitive, and rapid monitoring of acetylcholinesterase (AChE) enzyme activities. The method for enzyme monitoring was based on the reaction of the enzyme with $\mathrm{ACh}^{+}$substrate, while monitoring the decrease of $\mathrm{ACh}^{+}$concentration using the proposed $\mathrm{ACh}$ sensor.

\section{Results and Discussion}

\subsection{Sensors Performance Characteristics}

Acetylcholine reacts with sodium tetraphenylborate forming an acetylcholinium-tetraphenylborate (ACh/TPB) ion-associated complex in a stoichiometric ratio of 1:1. The resulting precipitate was purified, isolated, and dried. Two polymeric potentiometric acetylcholine sensors were based on the use of ACh/TPB (ACh/TPB/PEDOT/PSS-ISE) and tri acetyl- $\beta$-cyclodextrin ( $\beta$-CD/PEDOT/PSS-ISE) in a plasticized poly(vinyl chloride) (PVC) matrix. The polymeric membrane composition of the two sensors was $63.1 \mathrm{wt} . \%$ plasticizer, $32.4 \mathrm{wt} . \%$ PVC, $1.5 \mathrm{wt} . \%$ tetradodecylammonium tetrakis (4-chlorophenyl) borate (ETH 500), and $3.0 \mathrm{wt} . \%$ ionophore. All calibration plots for the proposed electrodes are shown in Figure 1. The obtained results from triplicate studies revealed a near-Nernstian slope of $56.4 \pm 0.6\left(R^{2}=0.999\right)$ and $55.3 \pm 1.1\left(R^{2}=0.998\right) \mathrm{mV} /$ decade, with detection limits of $2.00 \times 10^{-7}$ and $3.20 \times 10^{-7} \mathrm{M}$, for sensors I and II, respectively. The performance response characteristics are tabulated in Table 2.

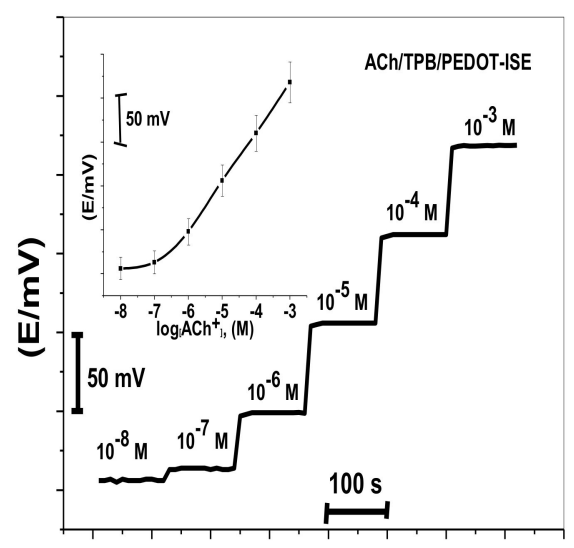

(Time/s)

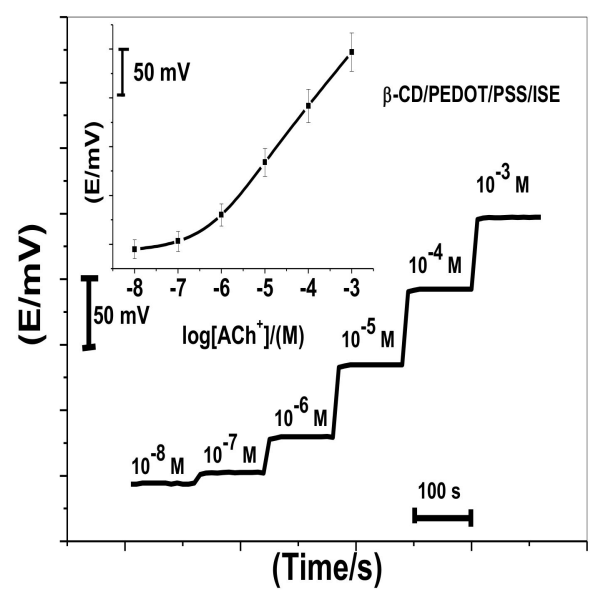

Figure 1. Potentiometric responses of the proposed sensors.

Table 2. Potentiometric response characteristics of acetylcholine membrane-based sensors.

\begin{tabular}{ccc}
\hline Parameter & ACh/TPB/PEDOT/PSS-ISE & $\beta$-CD/PEDOT/PSS-ISE \\
\hline Slope, $\left(\mathrm{mV} \text { decade }{ }^{-1}\right)^{*}$ & $56.4 \pm 0.6$ & $55.3 \pm 1.1$ \\
Correlation coefficient, $\left(R^{2}\right)$ & 0.999 & 0.998 \\
${\text { Linearity range, } \mathrm{M}^{*}}^{*}$ & $1.0 \times 10^{-6}-1 \times 10^{-3}$ & $2.0 \times 10^{-6}-1.0 \times 10^{-3}$ \\
Detection limit, $\mathrm{M}^{*}$ & $2.0 \times 10^{-7}$ & $3.2 \times 10^{-7}$ \\
Working range, $(\mathrm{pH})$ & $3-10$ & $4.5-10$ \\
Response time, $(\mathrm{s})$ & $<10$ & $<10$ \\
Accuracy, $(\%)$ & 99.2 & 99.3 \\
Precision, $(\%)$ & 0.6 & 0.7 \\
\hline
\end{tabular}

* Average of six measurements. After a rapid 10-fold increase in the concentration of $\mathrm{ACh}^{+}$, the time response of the screen-printed sensors to reach steady potential readings was $<5 \mathrm{~s}$. The time traces of the two proposed sensors are shown in Figure 1. 
The influence of $\mathrm{pH}$ on the proposed sensors was also investigated. Two different concentrations of $\mathrm{ACh}^{+}\left(10^{-4}-10^{-3} \mathrm{M}\right)$ were chosen for this test over a $\mathrm{pH}$ range of 2 to 10 . Sensors I and II revealed stable and unaffected potentials at the presented concentrations by $\mathrm{pH}$ changes over the working $\mathrm{pH}$ ranges 3-10 and 4.5-10, respectively. At $\mathrm{pH}>10$, the potentials sharply decreased due to interference from hydroxide ions. At $\mathrm{pH}<3$, the sensor responses were severely influenced by $\mathrm{H}_{3} \mathrm{O}^{+}$. A $10^{-2} \mathrm{M}$ concentration of phosphate-buffered saline (PBS) at pH 7 was chosen for all subsequent measurements.

The closeness of agreement between mutually independent repetitive test results obtained with a $10 \mu \mathrm{g} / \mathrm{mL}$ internal quality control ACh sample was measured using the proposed sensors and the same reagents during short intervals of time within one working day (within-day reproducibility), and a significantly small variation $( \pm 0.5 \%)$ from the final $\mathrm{mV}$ readings was noticed. Reproducibility of the results (day-to-day response variations) was also tested by measuring a $10 \mu \mathrm{g} / \mathrm{L}$ internal quality control ACh sample on five consecutive days using different batches of the reagents and daily recalibration. A small variation of the results compared to those obtained for repeatability experiments was obtained. Calculation of the relative standard deviation was found to be $1.7 \%$ and $2.2 \%$ for ACh/TPB/PEDOT/PSS-ISE and $\beta$-CD/PEDOT/PSS-ISE, respectively. These data indicate the good response stability of the proposed solid-contact (SC)/ISEs. After repeating the calibration of the sensors for at least 12 weeks, the long-term potential stability was tested. After six weeks of daily use, the detection limit increased to $7.0 \times 10^{-5} \mathrm{M}$ for both sensors and the sensitivity was found to decline. Considering the disposable nature of these types of sensors, the issue of decreasing sensitivity after six weeks was not taken as a big problem.

\subsection{Sensor Selectivity}

Selectivity behavior of the proposed sensors toward acetylcholine was tested over different common ions. The selectivity coefficients $\left(K_{A C h, J}\right)$ were evaluated using the separate solution method (SSM) modified by Bakker [38]. Table 3 presents the potentiometric selectivity coefficient values of all sensors. From the results shown in Table 3 , the selectivity of the sensor based on $\beta-C D(\beta-C D / P E D O T / P S S-I S E)$ toward $\mathrm{ACh}^{+}$ions over choline, methylamine, urea, dimethylamine, $\mathrm{Na}^{+}, \mathrm{Ca}^{2+}$, and $\mathrm{Mg}^{2+}$ ions was much better than the sensor based on ACh/TPB (ACh/TPB/PEDOT/PSS-ISE). This can be explained on the basis of the high affinity of tri acetyl- $\beta-C D$ toward complexation of acetylcholine as compared to other nitrogenous compounds. On the other hand, the sensor based on ACh/TPB/PEDOT/PSS-ISE (sensor I) revealed better selectivity toward $\mathrm{ACh}^{+}$over $\mathrm{K}^{+}$, histidine, ethylene diamine, hexamine, hydroxylamine, ephedrine, codeine, morphine, and alanine than $\beta$-CD/PEDOT/PSS-ISE.

Table 3. Selectivity values $\left(K^{p o t} A C h, j\right)$ for acetylcholine solid-contact sensors.

\begin{tabular}{|c|c|c|}
\hline \multirow{2}{*}{ Interferents } & \multicolumn{2}{|c|}{$\log K^{p o t} A C h, j$} \\
\hline & ACh/TPB/PEDOT/PSS-ISE & $\beta$-CD/PEDOT/PSS-ISE \\
\hline Choline & $-3.3 \pm 0.4$ & $-3.5 \pm 0.3$ \\
\hline $\mathrm{Na}^{+}$ & $-5.3 \pm 0.7$ & $-6.2 \pm 0.4$ \\
\hline $\mathrm{K}^{+}$ & $-5.3 \pm 0.3$ & $-5.1 \pm 0.1$ \\
\hline $\mathrm{Ca}^{2+}$ & $-6.8 \pm 0.4$ & $-7.1 \pm 0.4$ \\
\hline $\mathrm{Mg}^{2+}$ & $-7.1 \pm 0.1$ & $-7.3 \pm 0.6$ \\
\hline Urea & $-4.2 \pm 0.3$ & $-4.5 \pm 0.7$ \\
\hline Hexamine & $-4.3 \pm 0.2$ & $-4.1 \pm 0.6$ \\
\hline Ethylene diamine & $-6.2 \pm 0.2$ & $-6.1 \pm 0.4$ \\
\hline Dimethylamine & $-3.2 \pm 0.2$ & $-4.9 \pm 0.6$ \\
\hline Hydroxylamine & $-3.1 \pm 0.3$ & $-4.8 \pm 0.2$ \\
\hline Methylamine & $-3.3 \pm 0.4$ & $-4.5 \pm 0.3$ \\
\hline Histidine & $-4.5 \pm 0.3$ & $-4.1 \pm 0.4$ \\
\hline Alanine & $-4.4 \pm 0.4$ & $-4.3 \pm 0.2$ \\
\hline Ephedrine & $-3.3 \pm 0.4$ & $-1.2 \pm 0.3$ \\
\hline Codeine & $-2.7 \pm 0.3$ & $-1.0 \pm 0.2$ \\
\hline Morphine & $-2.9 \pm 0.6$ & $-1.1 \pm 0.1$ \\
\hline
\end{tabular}




\subsection{Effect of the PEDOT/PSS Solid-Contact Layer}

Short-term potential stability was studied using chronopotentiometry [39]. As shown in Figure 2, the typical chronopotentiograms of ACh/PEDOT/PSS-ISEs and $\beta$-CD/PEDOT/PSS-ISE, in addition to that of ACh/TPB-ISE and $\beta$-CD-ISE, are presented for comparison. The slope $(\Delta E / \Delta t)$ of the $E-t$ curve at longer times gives a direct measure of the potential stability of the ACh+-ISEs. The potential drifts were $6.5 \mu \mathrm{V} / \mathrm{s}$ and $52.0 \mu \mathrm{V} / \mathrm{s}$ for $\mathrm{ACh} / \mathrm{TPB} / \mathrm{PEDOT} / \mathrm{PSS}-\mathrm{ISE}$ and $\beta$-CD/PEDOT/PSS-ISE, respectively, which were much lower than those of ACh/TPB-ISE and $\beta$-CD-ISE $(117.0 \mu \mathrm{V} / \mathrm{s}$ and $90.2 \mu \mathrm{V} / \mathrm{s}$, respectively). From the data presented above, it was found that the potential stability of the proposed sensors was greatly improved by the introduction of PEDOT/PSS directly into the polymeric membrane. The capacitances were estimated to be $153.1 \mu \mathrm{F}$ and $19.1 \mu \mathrm{F}$ for ACh/TPB/PEDOT/PSS-ISE and $\beta$-CD/PEDOT/PSS-ISE, respectively. The capacitances of ACh/TPB-ISE and $\beta$-CD-ISE were $8.54 \mu \mathrm{V} / \mathrm{s}$ and $11.0 \mu \mathrm{V} / \mathrm{s}$, respectively. From these values, we can confirm the relationship between potential stability $(\Delta E / \Delta t)$ or the capacitance $(C)$ of ISEs and the presence of PEDOT/PSS as a solid-contact material between the membrane and the electrical substrate in the ISEs.

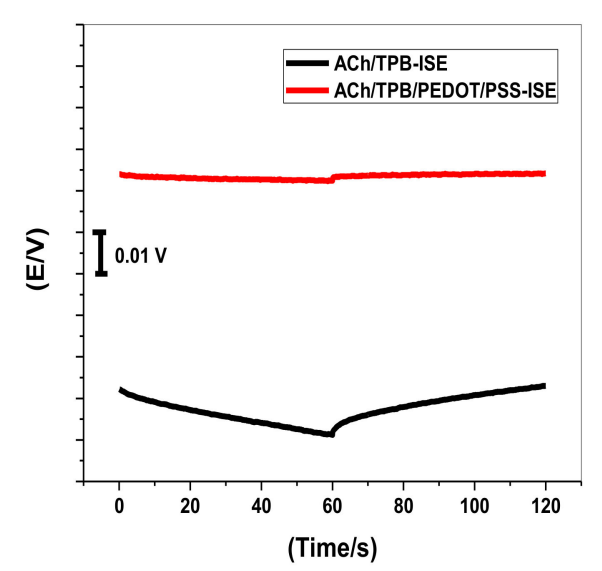

A

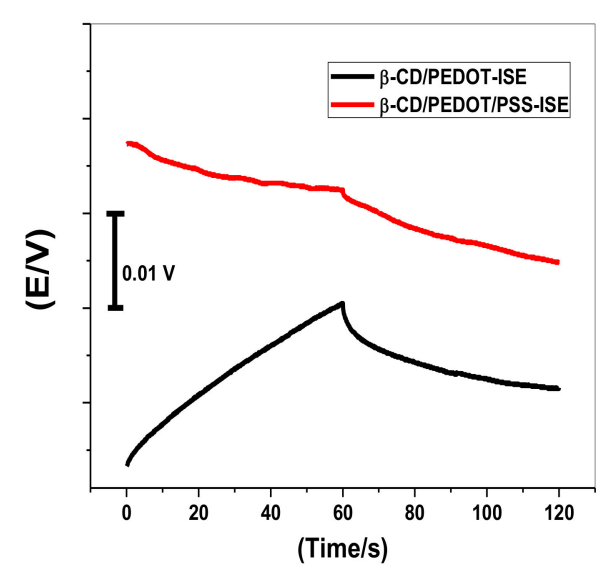

B

Figure 2. Chronopotentiograms (applied current: $+1 \mathrm{nA}$ for $60 \mathrm{~s}$ and $-1 \mathrm{nA}$ for $60 \mathrm{~s}$ ) for all-solid-state acetylcholine $\left(\mathrm{ACh}^{+}\right)$ion-selective electrode (ISE) based on (A) tetraphenylborate (TPB) and (B) $\beta$-cyclodextrin $(\beta-\mathrm{CD})$.

\subsection{Water-Layer Effect}

The water film formed between the ion-sensing membrane and electron conductor interface can act as localized microscopic pools of water [40]. It has a great influence on the potential stability and lifetime of the ISE. Thus, a test for water-layer absence was carried out for ACh/TPB/PEDOT/PSS-ISE. As shown in Figure 3, the proposed sensor was firstly conditioned in $10^{-3} \mathrm{M} \mathrm{CaCl}_{2}$ solution and the potential was then recorded for $1.0 \mathrm{~h}$. After that, the solution of $\mathrm{CaCl}_{2}$ was replaced with $1.0 \times 10^{-4}$ and $5 \times 10^{-6} \mathrm{M} \mathrm{ACh}^{+}$solution, and the potential was recorded for another $1.0 \mathrm{~h}$. After replacing $\mathrm{CaCl}_{2}$ solution with $\mathrm{ACh}^{+}$ion solution, the stable potential response for nearly $1.0 \mathrm{~h}$ showed complete absence of the undesirable water layer. This can be explained on the basis of the hydrophobic nature of PEDOT/PSS in the polymeric membrane. A similar $\mathrm{ACh}^{+}$selective membrane composition without PEDOT/PSS was also tested for comparison. A great potential drift was noticed in the absence of the PEDOT/PSS layer as a solid-contact material. This confirms the hydrophobic nature of this material and the absence of water-layer formation. 


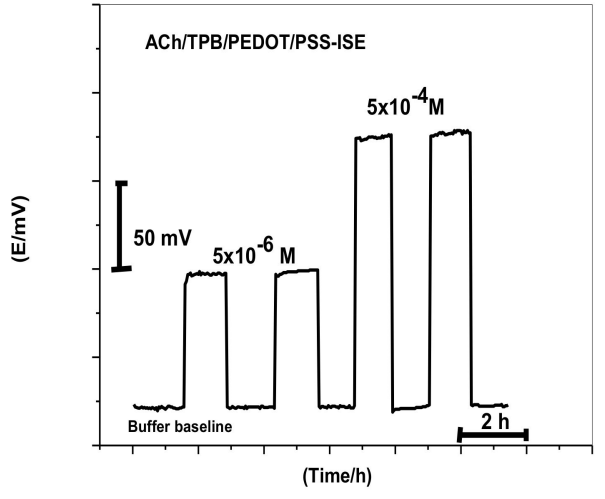

A

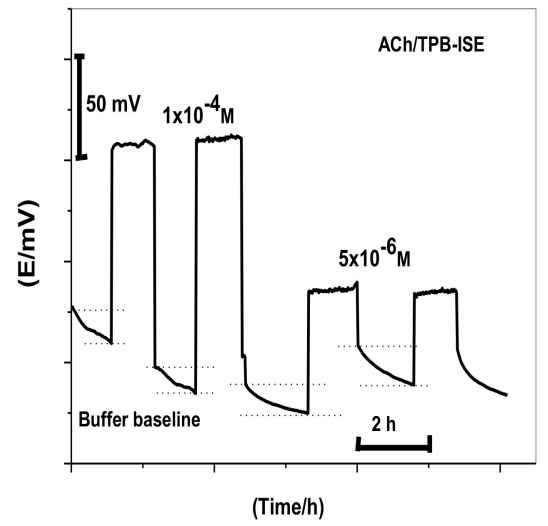

B

Figure 3. Water-layer tests for the acetylcholine ISE with and without poly(3,4-ethylenedioxythiophene)/ poly(styrenesulfonate) (PEDOT/PSS) solid-contact material for (A) ACh/TPB/PEDOT/PSS-ISE and (B) ACh/TPB-ISE.

\subsection{Hydrodynamic Assessment of $\mathrm{ACh}^{+}$}

The flow injection manifold of the system is shown in Figure 4. The flow cell used was prepared to afford a small sensor size. This design was used to avoid sample dispersion and to obtain a short recovery time for the potential response. Planar-type detectors (i.e., screen-printed electrodes) containing ACh/TPB- and $\beta$-CD-based membrane sensors were prepared and characterized by measuring $\mathrm{ACh}^{+}$ions under flow-through operation. The recorded potential signals of the sensors are presented in Figure 5. The sensors revealed a Nernstian response slope of $60.1 \pm 1.1$ and $52.7 \pm 0.8 \mathrm{mV} /$ decade over the linear range $1.0 \times 10^{-5}$ to $1.0 \times 10^{-3} \mathrm{M}$ and $2.0 \times 10^{-5}$ to $1.0 \times 10^{-3} \mathrm{M}$ with detection limits of $2.5 \times 10^{-6}$ and $3.9 \times 10^{-6} \mathrm{M}$ for ACh/TPB/PEDOT/PSS-ISE and $\beta$-CD/PEDOT/PSS-ISE, respectively. A value of $4 \mathrm{~mL} / \mathrm{min}$ was recommended as an optimized flow rate for measuring. All potentiometric characteristics are summarized in Table 4 . The relative standard deviation of the transient flow signals was $\pm 2.1 \%$ and $\pm 1.7 \%$ over the concentration range $1.0 \times 10^{-6}$ to $1.0 \times 10^{-2} \mathrm{M}$ $\mathrm{ACh}^{+}$ions for the proposed sensors, respectively.

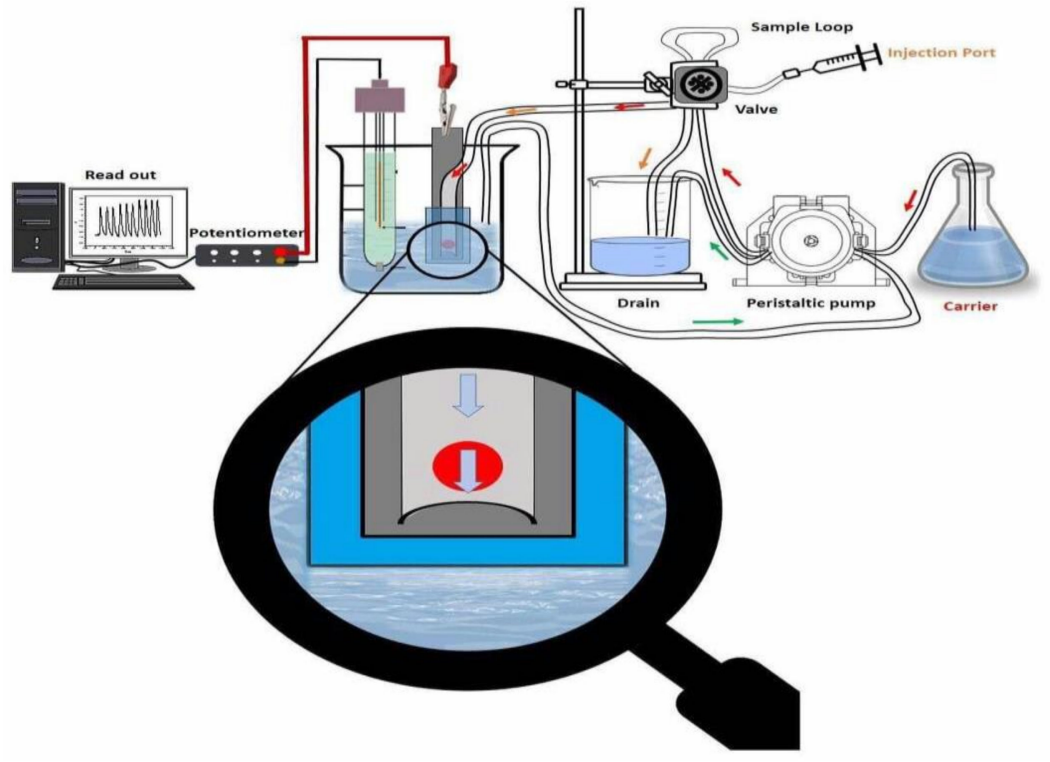

Figure 4. Flow injection manifold for $\mathrm{ACh}^{+}$quantification. Conditions: phosphate-buffered saline (PBS) (0.01 M, pH 7.0) carrier solution; $100 \mu \mathrm{L}$ was the injected sample volume with a $4.0 \mathrm{~mL} / \mathrm{min}$ flow rate. 


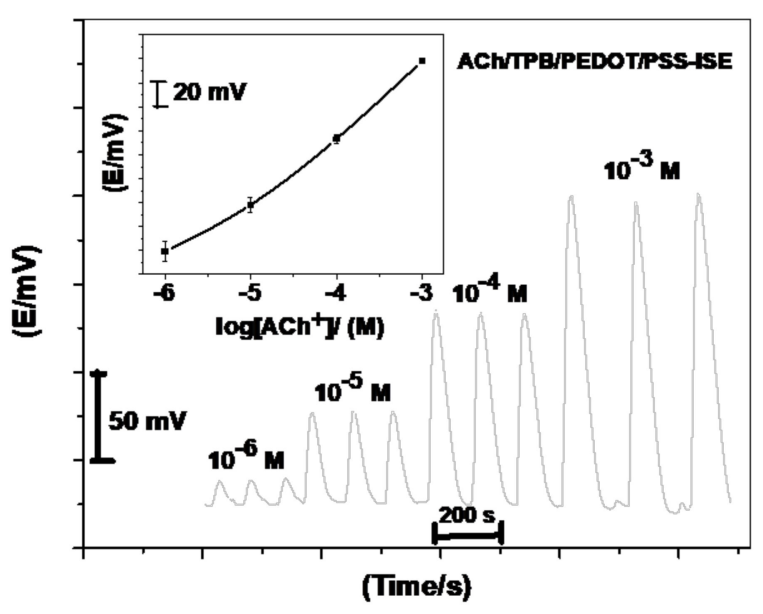

A

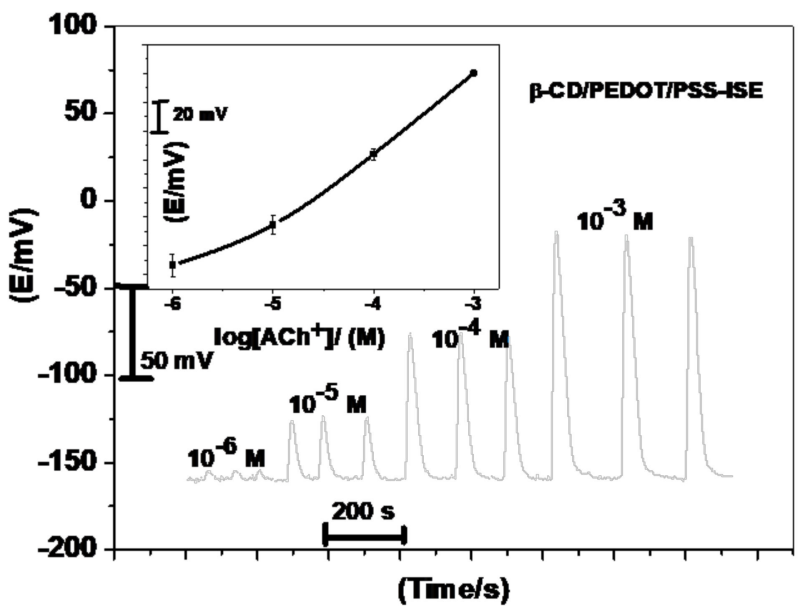

B

Figure 5. Flow injection signals for the evaluation of $\mathrm{ACh}^{+}$under the optimized flow injection conditions using: (A) ACh/TPB/PEDOT/PSS-ISE and (B) $\beta$-CD/PEDOT/PSS-ISE.

Table 4. Flow-through response characteristics of acetylcholine membrane-based sensors.

\begin{tabular}{ccc}
\hline Parameter & ACh/TPB/PEDOT/PSS-ISE & $\beta$-CD/PEDOT/PSS-ISE \\
\hline Slope $\left(\mathrm{mV} /\right.$ decade) ${ }^{*}$ & $60.1 \pm 1.1$ & $52.7 \pm 0.8$ \\
Correlation coefficient & 0.995 & 0.996 \\
Detection limit, $\left(\mathrm{M}^{*}\right)$ & $2.5 \times 10^{-6}$ & $3.9 \times 10^{-6}$ \\
Linear range, $\left(\mathrm{M}^{*}\right)$ & $1.0 \times 10^{-3}-1.0 \times 10^{-5}$ & $1.0 \times 10^{-3}-2.0 \times 10^{-5}$ \\
Optimized flow rate, $(\mathrm{mL} / \mathrm{min})$ & 4.0 & 4.0 \\
Life span, $($ week) & 8 & 8 \\
Sample throughputs, $(\mathrm{h})$ & $24-25$ & $29-30$ \\
\hline
\end{tabular}

* Average of six measurements.

\subsection{Acetylcholine Assay in Human Serum}

The usefulness of the proposed method was tested by determining ACh in collected human serum samples. For comparison with the present potentiometric procedure, the samples were also analyzed using a standard commercial spectrophotometric kit (No. ab65345, Abcam, Boston, MA, USA) at $25^{\circ} \mathrm{C}$. In this assay protocol, free choline is oxidized by choline oxidase to betaine and $\mathrm{H}_{2} \mathrm{O}_{2}$. The hydrogen peroxide is then detected with a highly specific colorimetric probe. Horseradish peroxidase is used as 
a catalyst for this reaction. The reaction products generate a color measure at $\lambda=540$ to $570 \mathrm{~nm}$. The results obtained from the standard and proposed methods are presented in Table 5. An F-test showed that there was no significant difference between means and variances of both the spectrophotometric and potentiometric sets of results.

Table 5. Potentiometric determination of ACh in human serum samples using ACh/TPB/PEDOT/PSS-ISE and spectrophotometry.

\begin{tabular}{ccccc}
\hline \multirow{2}{*}{ Sample } & \multirow{2}{*}{ Gender } & \multirow{2}{*}{ Age } & \multicolumn{2}{c}{ ACh Amount, $\mu \mathbf{M}^{*}$} \\
\cline { 3 - 5 } & & & Potentiometry & Spectrophotometry \\
\hline 1 & Male & $55-65$ & $0.60 \pm 0.03$ & $0.52 \pm 0.03$ \\
2 & Male & $35-50$ & $0.48 \pm 0.02$ & $0.55 \pm 0.04$ \\
3 & Male & $20-30$ & $0.71 \pm 0.01$ & $0.57 \pm 0.01$ \\
4 & Female & $40-55$ & $0.46 \pm 0.02$ & $0.41 \pm 0.02$ \\
5 & Female & $20-35$ & $0.53 \pm 0.04$ & $0.46 \pm 0.05$ \\
\hline
\end{tabular}

* Average of five measurements from each individual.

In addition, four different sensor assemblies with two different instruments on different days were used for repetitive determination of different sample sizes of ACh. Repeatability (within-day) and reproducibility (between-day) measurements showed potential variation in the range of 2-3 $\mathrm{mV}$. These results revealed that the influence of these parameters was within the specified tolerance and the variations are considered within the method's robustness range.

\subsection{Kinetic Monitoring of Acetylcholinesterase Activity}

Termination of the transmitted pulses in the cholinergic synapses is done via the fast hydrolysis of acetylcholine $(\mathrm{ACh})$ into choline $(\mathrm{Ch})$ and acetic acid as shown in Scheme 1 [41].

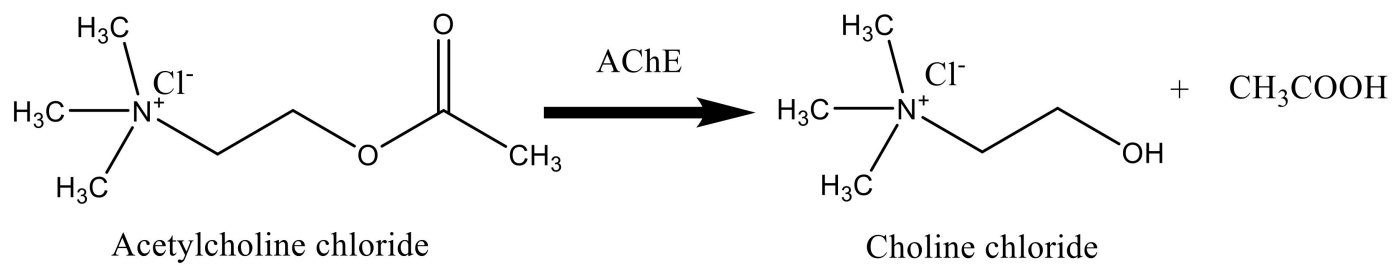

Scheme 1. Hydrolysis of $\mathrm{AChCl}$ by acetylcholinesterase (AChE).

In the enzymatic reaction, the reaction rate when the enzyme is saturated with substrate can be considered as the maximum rate of reaction $\left(V_{\max }\right)$, and $K_{m}$ is the concentration of substrate which permits the enzyme to achieve half $V_{\max }$. The values of $K_{m}$ and $V_{\max }$ of the enzymatic reaction were estimated using the proposed Ach sensor.

The potential change was recorded for different concentrations of $\mathrm{ACh}^{+}\left(1.0 \times 10^{-6}\right.$ to $\left.1.0 \times 10^{-3} \mathrm{M}\right)$ using fixed enzyme activity $\left(0.5 \mathrm{IU} \mathrm{L}^{-1}\right)$. At $1.0 \times 10^{-6}$, the measured initial rate had no significant increase. This is because of the low sensitivity of the sensor at low concentration levels of $\mathrm{ACh}^{+}$ ions. At concentrations $\geq 5.0 \times 10^{-5} \mathrm{M}$, the measured initial rate had a significant increase. The $1.0 \times 10^{-4} \mathrm{M} \mathrm{ACh}^{+}$solution was chosen for all subsequent AChE measurements because it revealed a good measurable change in the reaction rate at low activity for the enzyme. As shown in Figure 6, it provided values of $8.9 \times 10^{-5} \mathrm{M}$ and $59 \mathrm{mV} \mathrm{min}^{-1}$ for $K_{m}$, and $V_{m a x}$, respectively. This value of $K_{m}$ is close to the magnitude obtained previously [35,42]. 


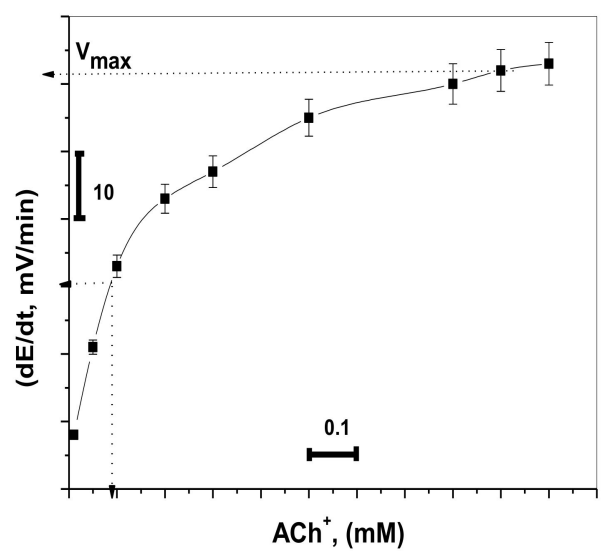

Figure 6. Initial reaction rates obtained by the proposed sensor fitted to the Michaelis-Menten equation (acetylcholinesterase (AchE) activity $=0.5 \mathrm{IU} / \mathrm{L}$ ).

For estimation of AChE activity, the $5.0 \times 10^{-4} \mathrm{M} \mathrm{ACh}^{+}$concentration was used as a fixed substrate concentration, and the activity of the enzyme was changed from $1.0 \times 10^{-3}$ to $6.0 \mathrm{IU} / \mathrm{L}$. The potential change was recorded versus time, and the initial rate was plotted versus AChE activity. A linear plot $\left(R^{2}=0.9994\right)$ was obtained in a concentration range of $5.0 \times 10^{-3}$ to $5.2 \mathrm{IU} / \mathrm{L}$ with a detection limit of $3.0 \times 10^{-3} \mathrm{IU} / \mathrm{L}$, as shown in Figure 7 .

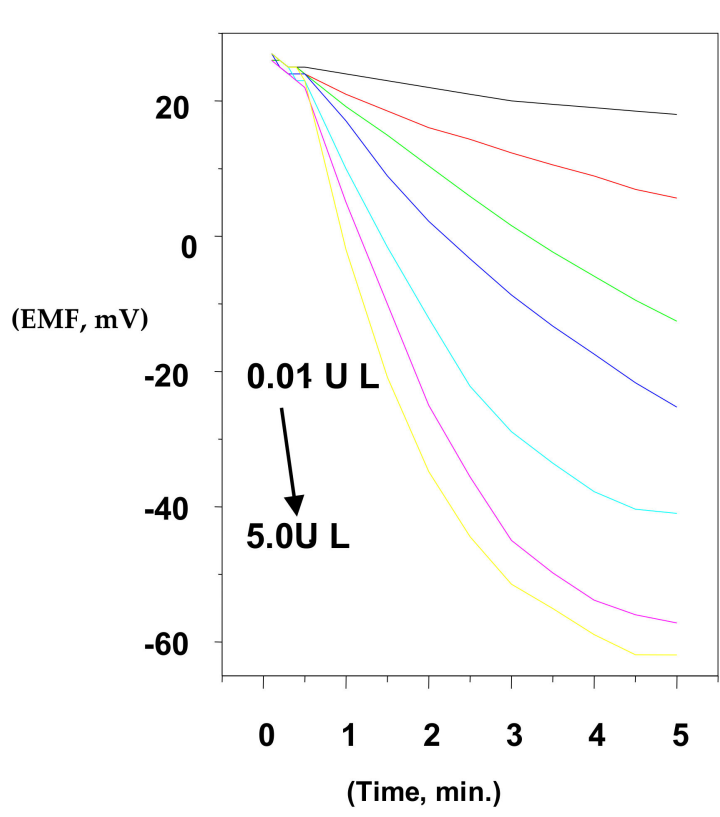

A

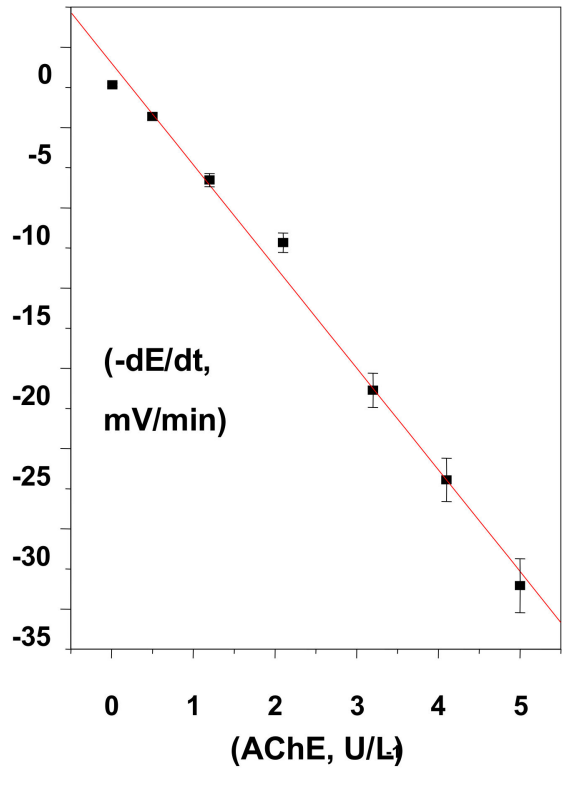

B

Figure 7. (A) Hydrolysis of ACh substrate using the initial rate method at $25^{\circ} \mathrm{C}$; (B) the calibration curve constructed for AChE quantification.

\section{Materials and Methods}

\subsection{Chemicals and Reagents}

All chemicals used in the work were of analytical grade and all solutions were prepared using deionized water (conductivity $<0.1 \mu \mathrm{S} \mathrm{cm}^{-1}$ ). Acetylcholine chloride (ACh), choline chloride $(\mathrm{Ch})$, creatinine (Creat), creatine (Crt), potassium tetrakis (4-chlorophenyl) borate (KTpClPB), sodium tetraphenylborate (NaTPB), 2-nitrophenyloctyl ether $(o, N P O E)$, tetradodecylammonium 
tetrakis (4-chlorophenyl) borate (ETH 500), poly (3,4-ethylenedioxythiophene)/poly-(styrenesulfonate) (PEDOT/PSS), triacetyl- $\beta$-cyclodextrin ( $\beta$-CD), and high-molecular-weight poly(vinyl chloride) (PVC) were purchased from Sigma Chemicals Co. (St. Louis, MO, USA). Tetrahydrofuran (THF) was purchased from Fluka (Ronkonoma, NY, USA). Acetyl cholinesterase (type VI-S) from Electrophorus electricus (electriceel, EC 3.1.1.7, $288 \mathrm{U} / \mathrm{mg}$ solid) was obtained from Sigma-Aldrich (Munich, Germany).

A $1.0 \times 10^{-1} \mathrm{M}$ stock $\mathrm{ACh}^{+}$solution was prepared by dissolving the salt in $100 \mathrm{~mL}$ of $0.05 \mathrm{M}$ phosphate-buffered saline solution (PBS), $\mathrm{pH}$ 7. The working standard solutions $\left(1.0 \times 10^{-2}-1.0 \times 10^{-8} \mathrm{M}\right)$ were prepared daily after stock solution dilution. For the potentiometric selectivity study, a $1.0 \times 10^{-2} \mathrm{M}$ interfering ion solution was also prepared using $0.05 \mathrm{M} \mathrm{PBS}$, pH 7 .

\subsection{Apparatus}

All EMF measurements were carried out at ambient temperature using a $\mathrm{pH} / \mathrm{mV}$ meter (Orion, Cambridge, MA, USA, model SA 720) connected with a data logger (Pico Technology Limited, model ADC-16). The flow injection (FI) manifold consisted of an Ismatech peristaltic pump (Ms-REGLO model) with polyethylene tubing $(0.71 \mathrm{~mm}$ internal diameter) for carrying solutions and an Omnifit injection valve (Omnifit, Cambridge, UK) with a loop sample of $100-\mu \mathrm{L}$ volume.

For potential stability and capacitance estimation of the solid-contact material used, chronopotentiometry tests were carried out in $10^{-3} \mathrm{M} \mathrm{ACh}^{+}$using a conventional three-electrode system cell. Double-junction $\mathrm{Ag} / \mathrm{AgCl}$ was used as a reference electrode, and a platinum plate was used as the auxiliary electrode. The applied constant current on the sensors was $\pm 1 \mathrm{nA}$ for $60 \mathrm{~s}$.

\subsection{ISE Membranes and Electrodes Measurements}

To the conductive carbon layer in the screen-printed platform (Figure 8), $10 \mu \mathrm{L}$ of PEDOT/PSS solution was applied by drop-casting on this orifice. After drying, a layer with a thickness close to $0.25 \mu \mathrm{m}$ was formed and used as the solid-contact layer. The sensor membrane was prepared by dissolving $100 \mathrm{mg}$ of the total components in $1.0 \mathrm{~mL}$ of THF:ionophore (3.0 mg), PVC (32.4 wt.\%), ETH $500(1.5 \mathrm{wt} . \%)$, and $o$-NPOE (63.1 wt.\%). Then, $20 \mu \mathrm{L}$ of the membrane cocktail was drop-cast onto the orifice in the screen-printed platform and allowed to dry for $6 \mathrm{~h}$.

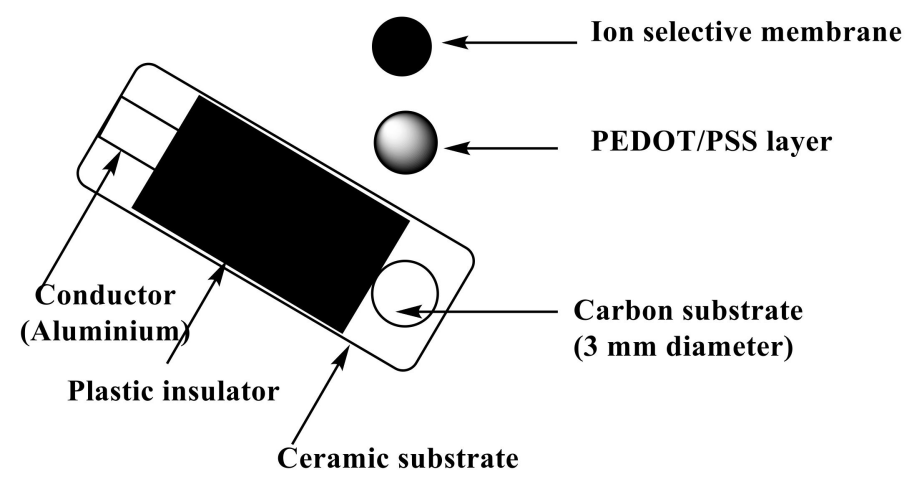

Figure 8. Schematic illustration of fabrication of the potentiometric screen-printed sensor.

The sensors were conditioned by their soaking in $1.0 \times 10^{-3} \mathrm{M}$ of $\mathrm{ACh}^{+}$aqueous solution for $2 \mathrm{~h}$. The $\mathrm{pH}$ of the test solution was maintained at 7.0 by the addition of different aliquots from standard $\mathrm{ACh}^{+}$solution in $25 \mathrm{~mL}$ of $0.01 \mathrm{M}$ PBS solution. The potential of the test solutions was measured at different concentrations of $\mathrm{ACh}^{+}$in the range $1.0 \times 10^{-8}$ to $1 \times 10^{-2} \mathrm{M}$. The EMF was plotted as a function of the logarithm of $\mathrm{ACh}^{+}$concentration.

\subsection{Acetylcholine Assay in Human Serum}

Different human blood samples were collected from different patients and analyzed within $3 \mathrm{~h}$ of extraction. The samples were collected in tubes and then mixed with $9 \mathrm{~mL}$ of absolute ethyl alcohol; 
they were left for $10 \mathrm{~min}$ before being centrifuged at $4000 \mathrm{rpm}$. The supernatant liquid was separated from the particulate matter and transferred into a 10-mL measuring flask and completed to the mark by $10^{-2} \mathrm{M}$ phosphate buffer solution of $\mathrm{pH}$ 7.2. The cell electrodes were immersed in the buffer solution, and the EMF readings were recorded after electrode potential stabilization. The amount of ACh was calculated using the constructed calibration plot between $\log \left[\mathrm{ACh}^{+}\right]$versus potential readings.

\subsection{Bioassay of Acetyl Cholinesterase Enzyme (AChE)}

To a thermo-stated vessel, a volume of $30.0 \mathrm{~mL}$ of the $\mathrm{pH} 7.0$ PBS was transferred, and the cell electrodes were immersed in the solution. After obtaining a stable potential reading for the electrochemical system, $1.0 \mathrm{~mL}$ of $10^{-2} \mathrm{M}$ of $\mathrm{ACh}^{+}$working solution was added. When the potential stabilized again, $100-\mu \mathrm{L}$ aliquots containing $1.0 \times 10^{-3}-6.0 \mathrm{IU} \mathrm{L}^{-1}$ of $\mathrm{AChE}$ enzyme were added. From the potential kinetic curve, the potential change with time $(\Delta E / \Delta t)$ expressed as initial rate $(t=0)$ was plotted versus enzyme activity. The obtained linear calibration curve was then used for all unknown enzyme activity monitoring. A blank experiment was also carried out under the same conditions but in the absence of the enzyme.

\section{Conclusions}

Herein, we focused on the demonstration of the value of miniaturized screen-printed solid-contact ISEs when facing a complex and relevant determination as an analytical challenge. The work deals with the preparation and characterization of potentiometric acetylcholine-selective membrane sensors using the carbon-based screen-printed ceramic substrate. The PEDOT/PSS showed excellent conductivity when used as the ion-to-electron transducer. The sensors developed were based on the use of TPB ion exchangers and tri acetyl- $\beta$-CD ionophore, $o$-nitropheyloctyl ether (o-NPOE) as a plasticizer, and PVC as a polymeric matrix. Improved accuracy and precision, good reproducibility, potential stability, rapid response, acceptable selectivity, and high sensitivity were obtained using these sensors. Possible interfacing with automated systems was also offered by these simple and cost-effective potentiometric biosensors. High sample throughputs ranged from 25-30 samples/h and excellent response characteristics were also obtained using the flow-through system. The activity of acetylcholinesterase $(\mathrm{AChE})$ was also determined using the proposed sensors. The enzyme activity holds $5.0 \times 10^{-3}-5.2 \mathrm{IU} / \mathrm{L}$.

Author Contributions: A.H.K., N.H.A., A.E.-G.E.A., and T.A.Y. conceptualized the study, interpreted the results, carried out the experiments, and prepared the manuscript; A.H.K. and A.E.-G.E.A. cooperated in the preparation of the manuscript; N.H.A., A.E.-G.E.A., A.A.A., and M.A.A.-O. performed the clinical studies. All authors read and approved the final manuscript.

Funding: The authors are grateful to the Deanship of Scientific Research, King Saud University for funding through the Vice Deanship of Scientific Research Chair.

Acknowledgments: The authors are grateful to the Deanship of Scientific Research, King Saud University for funding through the Vice Deanship of Scientific Research Chair.

Conflicts of Interest: The authors declare no competing interests.

Ethics: No special permit was required for the collection of serum samples.

\section{References}

1. Moon, J.; Thapliyal, N.; Hussain, K.K.; Goyal, R.N.; Shim, Y. Conducting polymer-based electrochemical biosensors for neurotransmitters: A review. Biosens. Bioelectron. 2018, 102, 540-552. [CrossRef] [PubMed]

2. Strandwitz, P. Neurotransmitter modulation by the gut microbiota. Brain Res. 2018, 1693, 128-133. [CrossRef]

3. Mesulam, M.M. Cholinergic Neurons, Pathways, Diseases. In Encyclopedia of Neuroscience; Adelman, G., Ed.; Birkhuser: Boston, MA, USA, 1987; Volume 1.

4. Watanabe, M.; Kimura, A.; Akasaka, K.; Hayashi, S. Determination of acetylcholine in human blood. Biochem. Med. Metab. Biol. 1986, 36, 355-362. [CrossRef] 
5. Fraunfelder, F.T.; Meyer, S.M. Drug-Induced Ocular Side Effects and Drug Interactions, 2nd ed.; Lea \& Febiger: Philadelphia, PA, USA, 1982.

6. Coulson, F.R.; Fryer, A.D. Muscarinic acetylcholine receptors and airway diseases. Pharmacol. Ther. 2003, 98, 59-69. [CrossRef]

7. Khayyal, M.T.; Tolba, H.M.; El-Hawary, M.B.; El-Wahed, S.A. A sensitive method for the bioassay of acetylcholine. Eur. J. Pharmacol. 1974, 25, 287-290. [CrossRef]

8. Feigenson, M.E.; Saelens, J.K. An enzyme assay for acetylcholine. Biochem. Pharmacol. 1969, 18, 1479-1486. [CrossRef]

9. Potter, P.E.; Meek, J.K.; Neff, N.H. Acetylcholine and Choline in Neuronal Tissue Measured by HPLC with Electrochemical Detection. J. Neurochem. 1983, 41, 188-194. [CrossRef]

10. Okuyama, S.; Ikeda, Y. Determination of acetylcholine and choline in human cerebrospinal fluid using high-performance liquid chromatography combined with an immobilized enzyme reactor: Ageing-induced change of acetylcholine level. J. Chromatogr. B 1983, 431, 389-394. [CrossRef]

11. MacDonald, R.C. A fluorometric assay for acetylcholine with picomole sensitivity. J. Neurosci. Methods 1989, 29, 73-76. [CrossRef]

12. Dong, Y.; Wang, L.; Shangguan, D.; Zhao, R.; Liu, G. Improved method for the routine determination of acetylcholine and choline in brain microdialysate using a horseradish peroxidase column as the immobilized enzyme reactor. J. Chromatogr. B 2003, 788, 193-198. [CrossRef]

13. Liberato, D.J.; Yergey, A.L.; Weintraub, S.T. Separation and quantification of choline and acetylcholine by thermospray liquid chromatography/mass spectrometry. Biomed. Environ. Mass Spectrom. 1986, 13, 171-174. [CrossRef] [PubMed]

14. Ishimaru, H.; Ikarashi, Y.; Maruyama, Y. Use of high-performance liquid chromatography continuous-flow fast atom bombardment mass spectrometry for simultaneous determination of choline and acetylcholine in rodent brain regions. Biol. Mass Spectrom. 1993, 22, 681-686. [CrossRef] [PubMed]

15. Hows, M.E.P.; Organ, A.J.; Murray, S.; Dawson, L.A.; Foxton, R.; Heidbreder, C.; Hughes, Z.A.; Lacroix, L.; Shah, A.J. High-performance liquid chromatography/tandem mass spectrometry assay for the rapid high sensitivity measurement of basal acetylcholine from microdialysates. J. Neurosci. Methods 2002, 121, 33-39. [CrossRef]

16. Dunphy, R.; Burinsky, D.J. Detection of choline and acetylcholine in a pharmaceutical preparation using high-performance liquid chromatography/electrospray ionization mass spectrometry. J. Pharm. Biomed. Anal. 2003, 31, 905-915. [CrossRef]

17. Kiba, N.; Ito, S.; Tachbana, M.; Tani, K.; Koizumi, H. Simultaneous determination of choline and acetylcholine based on a trienzyme chemiluminometric biosensor in a single line flow injection system. Anal. Sci. 2003, 19, 1647-1651. [CrossRef]

18. Bundel, D.D.; Sarre, S.; Eeckhaut, A.V.; Smolders, I.; Michotte, Y. Critical evaluation of acetylcholine determination in rat brain microdialysates using ion-pair liquid chromatography with amperometric detection. Sensors 2008, 8, 5171-5185. [CrossRef]

19. Schuvailo, S.V.; Dzyadevych, A.V.; Elskaya, A.V.; Gautier-Sauvigne, S.; Csoregi, E.; Cespuglio, R.; Soldatkin, A.P. Carbon fibre-based microbiosensors for in vivo measurements of acetylcholine and choline. Biosens. Bioelectron. 2005, 21, 87-94. [CrossRef]

20. Carballo, R.; Orto, V.C.D.; Rezzano, I. Poly [Ni (II) protoporphyrin IX] modified electrode for amperometric detection of acetylcholine (Ach) and choline (Ch). Anal. Lett. 2007, 40, 1962-1971. [CrossRef]

21. Jaffrezic-Renault, N.; Dzyadevych, S.V. Conductometric microbiosensors for environmental monitoring. Sensors 2008, 8, 2569-2588. [CrossRef]

22. Periasamy, A.P.; Umasankar, Y.; Chen, S.M. Nanomaterials-acetylcholinesterase enzyme matrices for organophosphorus pesticides electrochemical sensors-A Review. Sensors 2009, 9, 4034-4055. [CrossRef]

23. Moreira, F.T.C.; Guerreiro, J.R.L.; Azevedo, V.L.; Kamel, A.H.; Sales, M.G.F. New biomimetic sensors for the determination of tetracycline in biological samples: Batch and flow mode operations. Anal. Methods 2010, 2, 2039-2045. [CrossRef]

24. Hassan, S.S.M.; Mahmoud, W.H.; Mohamed, A.H.K.; Kelany, A.E. Mercury(II) Ion-Selective Polymeric Membrane Sensors for Analysis of Mercury in Hazardous Wastes. Anal. Sci. 2006, 22, 877-881. [CrossRef]

25. Hassan, S.S.M.; Elnemma, E.M.; Mohamed, A.H.K. Novel Biomedical Sensors for Flow Injection Potentiometric Determination of Creatinine in Human Serum. Electroanalysis 2005, 17, 2246-2253. [CrossRef] 
26. Hassan, S.S.M.; Marzouk, S.A.M.; Mohamed, A.H.K.; Badawy, N.M. Novel dicyanoargentate polymeric membrane sensors for selective determination of cyanide ions. Electroanalysis 2004, 16, 298-303. [CrossRef]

27. Kamel, A.H.; Galal, H.R.; Awaad, N.S. Cost-effective and handmade paper-based potentiometric sensing platform for piperidine determination. Anal. Methods 2018, 10, 5406-5415. [CrossRef]

28. Kamel, A.H.; Jiang, X.; Li, P.; Liang, R. A paper-based potentiometric sensing platform based on molecularly imprinted nanobeads for determination of bisphenol A. Anal. Methods 2018, 10, 3890-3895. [CrossRef]

29. Kamel, A.H.; Hassan, A.M.E. Solid Contact Potentiometric Sensors Based on Host-Tailored Molecularly Imprinted Polymers for Creatine Assessment. Int. J. Electrochem. Sci. 2016, 11, 8938-8949. [CrossRef]

30. Jaramillo, A.; Lopez, S.; Justice, J.B. Acetycholine and choline ion-selective microelectrodes. Anal. Chem. Acta 1983, 146, 149-159. [CrossRef]

31. Kima, H.; Oha, J.; Jeona, W.S.; Selvapalam, N.; Hwang, I.; Koa, Y.H.; Kim, K. A new cucurbit[6]uril-based ion-selective electrode for acetylcholine with high selectivity over choline and related quaternary ammonium ions. Supramol. Chem. 2012, 24, 487-491. [CrossRef]

32. Liu, W.; Yang, Y.H.; Wu, Z.Y.; Wang, H.; Shen, G.L.; Yu, R.Q. A potentiometric acetylcholinesterase biosensor based on plasma-polymerized film. Sens. Actuators B 2005, 104, 186-200. [CrossRef]

33. Poels, I.; Nagels, L. Potentiometric detection of amines in ion chromatography using macrocycle-based liquid membrane electrodes. Anal. Chim. Acta 2001, 440, 89-98. [CrossRef]

34. Khaled, E.; Hassan, H.N.A.; Mohamed, G.G.; Ragab, F.A.; Seleim, A.A. $\beta$-Cyclodextrin-based potentiometric sensors for flow-injection determination of acetylcholines. Int. J. Electrochem. Sci. 2010, 5, 448-458.

35. Kamel, A.H.; Al Hamid, F.A.; Soror, T.Y.; Galal, H.R.; Gendy, F.A. Solid contact biosensor based on man-tailored polymers for acetylcholine detection: Application to acetycholinesterase assay. Eur. Chem. Bull. 2016, 5, 266-273.

36. Sacramento, A.S.; Moreira, F.T.C.; Guerreiro, J.L.; Tavares, A.P.; Sales, M.G.F. Novel biomimetic composite material for potentiometric screening of acetylcholine, a neurotrans- mitter in Alzheimer's disease. Mater. Sci. Eng. C 2017, 79, 541-549. [CrossRef]

37. Cuartero, M.; Crespo, G.A. All-solid-state potentiometric sensors: A new wave for in situ aquatic research. Curr. Opin. Electrochem. 2018, 10, 98-106. [CrossRef]

38. Bakker, E. Determination of improved selectivity coefficients of polymer membrane ion-selective electrodes by conditioning with a discriminated ion. J. Electrochem. Soc. 1996, 143, L83-L85. [CrossRef]

39. Bobacka, J. Potential stability of all-solid-state ion-selective electrodes using conducting polymers as ion-to-electron transducers. Anal. Chem. 1999, 71, 4932-4937. [CrossRef]

40. Veder, J.; De Marco, R.; Clarke, G.; Chester, R.; Nelson, A.; Prince, K.; Pretsch, E.; Bakker, E. Elimination of undesirable water layers in solid-contact polymeric ionselective electrodes. Anal. Chem. 2008, 80, 6731-6740. [CrossRef]

41. Brunton, L.L. The Pharmacological Basis of Therapeutics, 11th ed.; McGraw Hill: New York, NY, USA, 2006.

42. Royani, I.; Widayani, I.; Abdullah, M.; Khairurrijal, K. An atrazine molecularly imprinted polymer synthesized using a cooling-heating method with repeated washing: Its physico-chemical characteristics and enhanced cavities. Int. J. Electrochem. Sci. 2014, 9, 5651-5662.

Sample Availability: Samples of the compounds are not available.

(C) 2019 by the authors. Licensee MDPI, Basel, Switzerland. This article is an open access article distributed under the terms and conditions of the Creative Commons Attribution (CC BY) license (http://creativecommons.org/licenses/by/4.0/). 